\title{
Room for Compulsory Product Liability Insurance in the European Union for Smart Robots? Reflections on the Compelling Challenges
}

\author{
Aysegul Bugra
}

\section{Background of the EU Initiative on Civil Law Rules on Robotics}

The Report with Recommendations to the Commission on Civil Law Rules on Robotics (2015/2103 (INL)) ${ }^{1}$ was prepared by the European Parliament Committee of Legal Affairs Rapporteur Mady Delvaux and was publicised in 2016. Amongst several issues raised in the Report such as the impact of the rise of robotics on education and employment forecast, ${ }^{2}$ intellectual property rights, flow of data ${ }^{3}$ and ethical principles, ${ }^{4}$ the main proposals made were in respect of civil liability rules that shall govern robotics with increased autonomous and cognitive features. Acknowledging the pace of the technological developments, the Report called upon the Commission to submit a proposal for a legislative instrument addressing the matters potentially to arise in the next 10-15 years in respect of robotics and

\footnotetext{
An earlier version of this chapter was awarded the Best Paper Prize by AIDA Europe in 2017 and was presented at the AIDA Europe Conference 2018 held in Warsaw, Poland in April 2018. The author is grateful to Ms. Helin Akbulut, Ms. Pinar Demiralp and Mr. Mucteba Faruk Ozdem for their research assistance on this chapter.
}

\footnotetext{
${ }^{1}$ Hereinafter referred to in the text as 'the Report'.

${ }^{2}$ The Report, paras 20-23.

${ }^{3}$ The Report, paras 10-12.

${ }^{4}$ The Report, paras 5-7.
}

\footnotetext{
A. Bugra $(\bowtie)$ (NASAMER), Istanbul, Turkey

Transport and Insurance Law, Koç University, Istanbul, Turkey e-mail: abugra@ku.edu.tr

Dr. Nüsret - Semahat Arsel International Business Law Implementation and Research Center 
artificial intelligence, which could be subject to an update later on. ${ }^{5}$ In particular, the Report considered the below-mentioned issues which shall further be elaborated in this chapter with a focus on the challenges they may generate:

- The adoption of strict liability as a rule for all the parties involved in the liability chain, ${ }^{6}$ including the manufacturers, owners, and users of robotics, ${ }^{7}$

- The introduction of a compulsory insurance scheme akin to the one existing in respect of liability arising from the harms caused by the use of motor vehicles, whereby the potentially liable parties would be required to take out insurance cover, $^{8}$

- The compulsory insurance scheme being supplemented by a compensation fund where the latter would serve the twin purposes of guaranteeing compensation to victims where no insurance cover is in place for the acts of robots, as well as collecting investments and donations made in respect of smart autonomous robots. $^{9}$

Based on the Report, the European Parliament issued a Resolution in February 2017 with Recommendations to the Commission ${ }^{10}$ reiterating that the product liability rules currently applicable in the European Union under the Product Liability Directive $^{11}$ could merely cover damage caused by the harmful acts or omissions of robots provided that the victim proves the damage, the defect in the product and the causal link between the defect and the damage. ${ }^{12}$ It was also further stated that once the parties who bear the ultimate responsibility are identified, their liability should be proportional to the actual level of instructions given to the robot. The Commission, in turn, agreed with the Parliament that an insurance system on robotics had to be well thought through, and also pronounced ${ }^{13}$ that they would assess whether legislative action is necessary following the conclusion of stakeholder consultation on product liability challenges in the context of the Internet of Things \& Autonomous Systems. ${ }^{14}$ Following the Resolution and the Commission Response, the European

\footnotetext{
${ }^{5}$ The Report, para 25.

${ }^{6}$ The Report, para 27.

${ }^{7}$ This proposal will be considered under Sect. 3.2 below on product liability.

${ }^{8}$ The Report, para 31(a).

${ }^{9}$ The Report, para 31(b).

${ }^{10}$ European Parliament Resolution of 16 February 2017 with Recommendations to the Commission on Civil Law Rules on Robotics (2015/2013(INL)), hereinafter referred to as 'the Resolution'.

${ }^{11}$ Council Directive 85/374/EEC of 25 July 1985 on the Approximation of the Laws, Regulations and Administrative Provisions of the Member States concerning Liability for Defective Products.

${ }^{12}$ The Resolution, para AH.

${ }^{13}$ Follow up to the European Parliament Resolution of 16 February on Civil Law Rules on Robotics http://www.europarl.europa.eu/meetdocs/2014_2019/plmrep/COMMITTEES/JURI/DV/2017/1120/A8-0005-2017_EN.pdf (last accessed, 2 November 2018).

${ }^{14}$ Follow up to the European Parliament Resolution of 16 February on Civil Law Rules on Robotics http://www.europarl.europa.eu/meetdocs/2014_2019/plmrep/COMMITTEES/JURI/DV/2017/1120/A8-0005-2017_EN.pdf, at p. 3.
} 
Parliament published a European Added Value Assessment in respect of connected and autonomous vehicles in February 2018. ${ }^{15}$ In April 2018, a Commission Staff Working Document on liability for emerging digital technologies, ${ }^{16}$ and in May 2018, the stakeholder and public consultation on the Product Liability Directive were completed and made public. ${ }^{17}$

The European Commission, following the Parliament's Added Value Assessment, opened a public consultation ${ }^{18}$ and is currently working towards another Added Value Assessment on robotics and artificial intelligence, which is due in 2018-2019. ${ }^{19}$ As in the case of autonomous and connected vehicles, the analysis of possible policy options for robots are presumably to be conducted in the light of the criteria of legal certainty, potential litigation burden, impact on consumer protection and innovation, degree of dependence on soft law, political acceptance and degree of regulatory intervention required. ${ }^{20}$

The initiative of the Parliament appears to be timely as some legislative steps have already been undertaken in some Member and non-Member States covering insurance of autonomous and intelligent systems. ${ }^{21}$ A cautious yet determined approach to the regulation of civil liability rules and insurance would also need to be adopted in the European Union with a view to allow the sustainability of product innovation without compromising on the protection of the rights of product users. Careful steps would accordingly need to be made towards the implementation of a system adjustable to the changing needs, without overenthusiastically seeking to introduce

\footnotetext{
${ }^{15}$ A Common EU Approach to Liability Rules and Insurance for Connected and Autonomous Vehicles European Added Value Assessment, February 2018 available at: http://www.europarl. europa.eu/RegData/etudes/STUD/2018/615635/EPRS_STU(2018)615635_EN.pdf (last accessed, 2 November 2018). Hereinafter referred to as "The Added Value Assessment on Autonomous Vehicles".

${ }^{16}$ Commission Staff Working Document - Liability for Emerging Digital Technologies- Accompanying the document Communication from the Commission to the European Parliament, the European Council, the Council, the European Economic and Social Committee and the Committee of the Regions Artificial intelligence for Europe SWD (2018) 137 final COM (2018) 237 final.

${ }^{17}$ Evaluation of Council Directive 85/374/EEC on the approximation of laws, regulations and administrative provisions of the Member States concerning liability for defective products - Final Report, January 2018, p. 23. This Report is hereinafter referred to as "The Final Report on the Evaluation of Council Directive 85/374/EEC".

${ }^{18}$ European Commission Public Consultation on Recommendation on Connected and Automated Mobility (CAM) available at https://ec.europa.eu/info/consultations/public-consultation-recommen dation-connected-and-automated-mobility-cam_en (last accessed, 2 November 2018).

${ }^{19}$ A Common EU Approach to Liability Rules and Insurance for Connected and Autonomous Vehicles European Added Value Assessment, February 2018 available at: http://www.europarl. europa.eu/RegData/etudes/STUD/2018/615635/EPRS_STU(2018)615635_EN.pdf (last accessed, 2 November 2018), p. 14, fn 43.

${ }^{20}$ The Added Value Assessment on Autonomous Vehicles, p. 6.

${ }^{21}$ Automated and Electric Vehicles Act 2018 of the United Kingdom which received Royal Assent on 19 July 2018; Intelligent Robots Development and Distribution Act 2008 of South Korea, whereby certain insurance businesses are granted the right to operate a business for the purpose of providing cover for third party damages caused by intelligent robots.
} 
future-proof rules that would hamper the speed of innovation. As the re-evaluation of product liability rules in the light of new technologies was carried out in the European Union as a priority, and because it was also proposed in the Resolution that product liability insurance should be made compulsory for the producers of robotics, ${ }^{22}$ this chapter seeks to provide an assessment of the potential risks that may emerge from adopting a compulsory product liability insurance scheme. ${ }^{23}$ Regard will accordingly be had on the challenges pertaining to the definition of smart robots and their classification as 'product' and 'service' (Sect. 2); on whether the functions of compulsory insurance would justify its introduction in the product liability sphere and how this may impinge on the moral hazard of producers (Sect. 3); and on what problems may the victims face in the claims process should such scheme be adopted (Sect. 4).

\section{Challenges on Definition and Demarcation}

The term 'robotics' used in the Report and the Resolution is seemingly meant to cover a wide range of devices. Given the numerous features they exhibit, clarity would be needed as to whether the same civil liability regime and insurance scheme shall be applicable in respect of the entirety thereof. Neither the Report nor the Resolution provide a common understanding as to the meaning of 'robotics'. This task is left to the Commission as regards cyber physical systems, autonomous systems, smart autonomous robots and their subcategories, ${ }^{24}$ together with the assessment as to the very necessity of such definition. The European Parliament, although not having proposed a definition, agreed on several characteristics of 'smart robots' which were expressed as "the acquisition of autonomy through sensors and/or by exchanging data with its environment (inter-connectivity) and the trading and analysing of those data; self-learning from experience and by interaction (optional criterion); at least a minor physical support; the adaptation of its behaviour and actions to the environment; [and] absence of life in the biological sense". ${ }^{25}$ Some assistance can also be offered by the approach to robots adopted in the Final Report on the Evaluation of Council Directive 85/374/EEC, which seeks to define it by reference to the Oxford Dictionary definition ${ }^{26}$ : A robot is "a machine capable of

\footnotetext{
${ }^{22}$ The Resolution, p. 18.

${ }^{23}$ It is noteworthy that because the issues analysed in this chapter centre on robotics as 'products', the discussions on robots as artefacts classified as 'subjects' in law rather than 'objects' will not be considered. On that point, see the Resolution, para 59(f); see also Teubner (2018) on electronic personality of autonomous software agents.

${ }^{24}$ See the Resolution, para 1.

${ }^{25}$ The Resolution, para 1.

${ }^{26}$ See the Final Report on the Evaluation of Council Directive 85/374/EEC, p. 174.
} 
carrying out a complex series of actions automatically, especially one programmable by a computer". ${ }^{27}$ The avoidance of restrictive definitions was also clear in other contexts where it was provided that the term 'robot' could have differing meanings for everyone, and that it was increasingly difficult to explain their differences from other objects and systems given the pace in technology. ${ }^{28}$

Despite the underlying challenges on definition and demarcation, an almost evident category of smart robots is automated vehicles (AVs) which have already been considered by the Parliament as urgently requiring efficient rules applicable to the automotive sector. ${ }^{29}$ Some assistance as to what may be covered under the regime proposed by the Parliament other than autonomous vehicles can be found by reference to the Final Report on the Evaluation of Council Directive 85/374/EEC. New technological developments considered therein are software embedded products; apps and other non-embedded software; Internet of Things; products shared with other users through collaborative platforms; devices for 3D printing; advanced robots and autonomous systems with artificial intelligence, ${ }^{30}$ and software-based systems empowered with artificial intelligence. ${ }^{31}$ Most of these systems are classified as 'product' within the meaning of the Product Liability Directive as they are 'movable' objects ${ }^{32}$ — and tangible - with perhaps the exception of 'software' which can both be regarded as 'information' that is intangible by definition, and also having a physical aspect given that it can be embedded in devices. ${ }^{33}$

As per the proposals in the Resolution, the classification of a smart robot as 'product' would require its producer to purchase compulsory insurance for damages arising from defects in it. Where a smart device is not qualified as such, liability will be channelled to the providers of the service which would trigger a civil liability regime that is different than the one under the Product Liability Directive.

\footnotetext{
${ }^{27} \mathrm{https} / / /$ en.oxforddictionaries.com/definition/robot.

${ }^{28}$ Regulating Emerging Robotic Technologies in Europe: Robotics facing Law and Ethics, D6.2 Guidelines on Robotics http://www.robolaw.eu/RoboLaw_files/documents/robolaw_d6.2 guidelinesregulatingrobotics_20140922.pdf, at p. 15 (last accessed, 2 November 2018); Leenes et al. (2017), pp. 3-4. See also Palmerini et al. (2016), p. 79 for the view that autonomy, ability to work in physical environments and human-likeness may not constitute sufficient criteria for categorising 'things' as robots, on the ground that surgery robots are non-autonomous, softbots are non-physical and industrial robots are not human-like.

${ }^{29}$ Mapping the Cost of Non-Europe 2014-2019, p. 150. An insurance model proposed to be applicable in this regard was a special no-fault insurance scheme that supplements the injured party's entitlement to social security benefits, and that replaces civil liability claims for damages (The Added Value Assessment on Autonomous Vehicles, p. 115).

${ }^{30}$ This was explained as "physical machines perceiving their environment processing this information correctly and then carrying out a complex and adequate actions autonomously, e.g. advanced driver assistance systems or completely self-driving cars, these systems can also learn from their actions" in the Final Report on the Evaluation of Council Directive 85/374/EEC, p. 166.

${ }^{31}$ The Final Report on the Evaluation of Council Directive 85/374/EEC, p. 166.

${ }^{32}$ Within the meaning of the Product Liability Directive Art. 2.

${ }^{33}$ The Final Report on the Evaluation of Council Directive 85/374/EEC, p. 174.
} 
The below section will therefore seek to shed light on the demarcation problem surrounding robots as 'product' with a view to assess whether the proposal on compulsory product liability insurance is realistically necessary and attainable in this respect.

\subsection{Smart Robots as 'Product'}

As much as the perception of robots being commercially available may seem sufficient in other disciplines to regard them as 'product', 34 the definition of 'product' in the Product Liability Directive is confined to movables as tangible objects, ${ }^{35}$ leaving out intangibles or services. ${ }^{36}$ The latter can nevertheless give rise to the liability of their manufacturers where domestic laws of the Members States contain adequate provisions applicable thereto. Moreover, certain technologies such as cloud computing systems could give rise to debates as to whether they shall be regarded as 'service' rather than as 'product'. 37

The assessment of what artefacts could qualify as 'product' is a pertinent query for the purposes of insurance, particularly given that one of the proposals in the Resolution is the adoption of rules requiring producers to take out insurance, which has not been a common practice for this insurance line. The systems not qualifying as such yet are put into circulation as 'services' will not trigger the requirement for compulsory product liability insurance. They will nevertheless pose the risk of damage to third parties either in the form of death/bodily injury or property loss. The query that may accordingly ensue is whether third party protection through an efficient mechanism of compensation will be sought to be implemented through the requirement of compulsory commercial liability insurance in respect of robots that are considered as 'service'. Given that robots as 'product', i.e. as tangible objects, are more likely to cause both personal injury and property damages to third parties compared to robots qualified as 'service', a policy decision to require compulsory insurance (if at all) may be relatively more justified in the previous case than in the latter. $^{38}$

\footnotetext{
${ }^{34}$ Engineering and Physical Sciences Research Council (EPSRC) Principles of Robotics, Principle 3. For a critique of the Principles, see Boddington (2017), pp. 170-176; Müller (2017), pp. 137-141.

${ }^{35}$ The Final Report on the Evaluation of Council Directive 85/374/EEC, p. 175.

${ }^{36}$ The Final Report on the Evaluation of Council Directive 85/374/EEC, p. 69.

${ }^{37}$ The Final Report on the Evaluation of Council Directive 85/374/EEC, p. 27.

${ }^{38}$ Whether or not the introduction of compulsory product liability insurance is necessary and adequate has separately been elaborated below in Sect. 3 .
} 
A further grey area may appear with respect to smart robots which have not yet been put into circulation by their manufacturers. A product would need to be in circulation for attracting the application of the Product Liability Directive and any smart robot that is tangible and movable, although not yet in circulation, would therefore be subject to the national liability regimes covering damage caused to third parties. ${ }^{39}$ A policy decision requiring compulsory insurance at the EU level would accordingly not extend to this circumstance. Provided the robot constitutes a 'final machinery' in the sense ascribed in Art. 2(g) of the Machinery Directive, ${ }^{40}$ it would be subject to the health and safety requirements that would have to be complied with. It is also noteworthy that for this Directive to apply, the robot would need to be a "stand and function alone robot", and not a robot that would have to be incorporated into another system to operate. ${ }^{41}$ Because smart robots as products not yet put into circulation-and not subject to the rules under the Product Liability Directivewould not pose the same level of risk that products put into circulation would do, requiring insurance cover for these circumstances would be hardly justified.

\footnotetext{
${ }^{39}$ Currently product liability rules applicable specifically to smart robots do not exist in any of the Member States, see also on this point the Final Report on the Evaluation of Council Directive $85 / 374 /$ EEC, p. 37 . Therefore, in theory, this eventuality would be subject to the national liability rules.

${ }^{40}$ Directive 2006/42/EC of the European Parliament and of the Council of 17 May 2006 on machinery, and amending Directive 95/16/EC (recast). The Machinery Directive aiming at harmonising the health and safety requirements applicable to machinery for consumer and industrial use as well as ensuring the free circulation of machinery within the EU has recently been evaluated as to its applicability to autonomous robots and artificial intelligence, see the European Commission Staff Working Document - Evaluation of the Machinery Directive - SWD (2018) 160 final. It was enunciated in this document that the definition of 'machinery' covered a wide range of devices spanning "from personal care robots or collaborative robots to complete automated industrial production lines", para 2.1.

${ }^{41}$ See the example of an industrial 'stand and function-alone robot' that constitutes a complete machinery under the Machinery Directive, as opposed to the example of an industrial robot designed without a specific application until incorporated into the final machinery that does not qualify as such, European Commission Directorate-General for Internal Market, Industry, Entrepreneurship and SMEs Industrial Transformation and Advanced Value Chains Advanced Engineering and Manufacturing Systems, Guide to Application of the Machinery Directive 2006/42/EC Edition 2.1 - July 2017 (Update of 2nd Edition), p. 48.
} 


\section{Checks and Balances of the Scheme Proposed: Control of 'Moral Hazard'}

The European Parliament proposed in their Resolution that "An obligatory insurance scheme, which could be based on the obligation of the producer to take out insurance for the autonomous robots it produces, should be established." 42 Currently, in the European Union, the duty to take out insurance exists in a number of instruments. To name but few, these are the Motor Insurance Directive, ${ }^{43}$ the Regulation on Insurance Requirements for Air Carriers and Aircraft Operators, ${ }^{44}$ and the Directive on the Insurance of Shipowners for Maritime Claims. ${ }^{45}$ The proposals in the Resolution and the Report drew an analogy between the compulsory insurance system in place in respect of motor third party liability under the Motor Insurance Directive, and the one that is sought to be implemented in respect of smart robots. ${ }^{46}$ The below sub sections seek to address whether this analogy is well-founded by reference to the functions of compulsory insurance and the nature of motor and product liabilities. They also provide an overview of circumstances which may impinge on the moral hazard of smart robot producers and how measures taken to control the moral hazard may affect third parties.

\subsection{Functions of Compulsory Insurance and the Analogy Between Compulsory Motor Liability and Compulsory Product Liability Insurance}

Compulsory insurance is one of the effective mechanisms in dealing with the compensation of third party losses effectively. Albeit it may be difficult to enumerate all the circumstances which would justify the adoption of a compulsory insurance scheme, certain common parameters can be noticed in analysing the areas where the duty to take out insurance was imposed. One of these parameters would be the protection of the potential wrongdoer who may not necessarily be in a position to effectively assess the likely advantages of having insurance ${ }^{47}$ for whom the

\footnotetext{
${ }^{42}$ The Resolution, Annex to the Resolution: Recommendation as to the Content of the Proposal Requested, p. 18.

${ }^{43}$ Directive 2009/103/EC of the European Parliament and of the Council of 16 September 2009 relating to insurance against civil liability in respect of the use of motor vehicles, and the enforcement of the obligation to insure against such liability, Art. 3.

${ }^{44}$ Regulation (EC) No 785/2004 of the European Parliament and of the Council of 21 April 2004 on insurance requirements for air carriers and aircraft operators, Art. 4.

${ }^{45}$ Directive 2009/20/EC of the European Parliament and of the Council of 23 April 2009 on the insurance of shipowners for maritime claims, Art. 4.

${ }^{46}$ The Resolution, para 59(a); the Report, para 31(a).

${ }^{47}$ Faure (2016), p. 320.
} 
insolvency risk may increase. This may be one of the reasons why motorists, who may often underestimate the potential consequences of driving both for themselves and others, are required to take out insurance. Similarly, insurance was also imposed in the European Union in respect of the operations of air carriers and aircraft operators, the operations of which have notably been regarded by the EU as carrying a great potential of insolvency risk. ${ }^{48}$ The analysis of such potential was studied following the impact assessments conducted before the adoption of the relevant regulations, ${ }^{49}$ and the operation of the insurance scheme adopted was assessed through minutely prepared reports. ${ }^{50}$

A second, and perhaps more obvious justification for compulsory insurance is the efficient protection of third parties affected by the actions of the wrongdoer. Compulsory liability insurance would in this sense serve the tort liability norm of compensatory justice. Third parties would particularly benefit from compulsory insurance where the tort liability judgment exceeds the wealth of the wrongdoer/ insured: Instead of being under-compensated by the insured, they would recourse to insurance, provided they have a right of direct action against the liability insurers. The risk of the victim in failing to be fully compensated is accordingly sought to be avoided by the introduction of compulsory insurance, as is the case in the European Union under the Motor Insurance Directive.

The scheme proposed by the European Parliament begs the question of whether insurance for product liability shall indeed be made compulsory for the manufacturers of smart robots. It is noteworthy that this suggestion was also formerly raised by the UK Department for Transport (DfT) in their Consultation on Automated Vehicles. It was initially proposed by the DfT that compulsory motor insurance should be extended to cover product liability in circumstances where the motorists were not in charge of the vehicle (i.e. where the vehicle was on autonomous mode). ${ }^{51}$ This had required the owner of the vehicle to take out insurance that covered both the manufacturer's and other entities' product liability which would have responded to

\footnotetext{
${ }^{48}$ The EU has specific legislation applicable to the measures that are required to be taken by insurance businesses for avoiding the insolvency risk, however compulsory insurance may be an effective mechanism as it has a dual effect of both protecting the policyholder ('wrongdoer' under a liability insurance policy) and the third parties affected by the acts of the policyholder.

${ }^{49}$ E.g. Communication from the Commission to the European Parliament and the Council Insurance Requirements for Aircraft Operators in the EU - A Report on the Operation of Regulation 785/2004 COM (2008) 216 final.

${ }^{50}$ E.g. Commission Staff Working Document Impact Assessment - Accompanying the document Proposal for a Directive of the European Parliament and of the Council amending Directive 2009/ 103/EC of the European Parliament and the Council of 16 September 2009 relating to insurance against civil liability in respect of the use of motor vehicles, and the enforcement of the obligation to insure against such liability.

${ }^{51}$ Para 1.3 at: https://assets.publishing.service.gov.uk/government/uploads/system/uploads/attach ment_data/file/536365/driverless-cars-proposals-for-adas-and_avts.pdf (last accessed, 10 November 2018).
} 
the claims by the 'not-at-fault vehicle driver' while the vehicle was on autonomous mode, as well as the ones by the passengers and third parties. ${ }^{52}$ This approach was later on abandoned in favour of another policy requiring less radical changes based on the response received from the automotive and insurance industries. The relevant policy advocated a single insurer model (covering both the driver's use of the vehicle and the AV technology) where the third party victim would have a right of direct action against the motor insurer, who would in turn have a right of recourse against the responsible party, where for instance the loss is caused by product failure. ${ }^{53}$ This solution was advanced in the anticipation that product liability and motor insurers would in the future develop instruments so as to deal with the recourse stage as efficiently as possible, and that the government should have left the market dynamics play an active role without adopting an over-regulatory approach.

The obvious concern with respect to the analogy drawn in the Resolution and Report would lie in that in the case of product liability insurance, the insured will be a commercial entity (producer) and in the case of motor liability insurance, mostly a consumer with a rather limited wealth. Imposing a duty to take out insurance would therefore arguably be more justified in the latter case than in the former as there would be a greater risk that the damages would exceed the wealth of the insured and the third parties may accordingly be protected against this risk through compulsory insurance. One other remark could perhaps be expressed as regards robot producers having financial assets that are greater compared to the sources that the insurance companies can offer. In these types of cases self-insurance may arguably appear as a more convenient option as regards the level of protection guaranteed. ${ }^{54}$

A further reason why the abovementioned analogy may be regarded as rather unfit rests upon the distinction between the markets for motor vehicles and robotics: As much as the former is predictable in terms of insurable risks, the same is yet to be achieved with respect to the latter. Furthermore, there needs to be a sufficiently large number of insureds bearing risk exposure profiles that are alike for the insurer to refer to past risk profiling experience to accurately predict and accordingly quantify

\footnotetext{
${ }^{52}$ https://assets.publishing.service.gov.uk/government/uploads/system/uploads/attachment_data/ file/536365/driverless-cars-proposals-for-adas-and_avts.pdf, para 2.9.

${ }^{53}$ Pathway to driverless cars: Consultation on proposals to support Advanced Driver Assistance Systems and Automated Vehicles, Government Response available at https://assets.publishing. service.gov.uk/government/uploads/system/uploads/attachment_data/file/581577/pathway-to-driv erless-cars-consultation-response.pdf (last accessed, 22 September 2018), para 1.10.

${ }^{54}$ Faure (2016), p. 324 refers to the example of the Carbon Capture and Storage (CCS) Directive 2009/31/EC on the geological storage and carbon dioxide, where Art. 7(10) requires that applications for storage permits must be accompanied by proof of financial security; yet is flexible as to the form thereof which could include self-insurance. Multifarious alternatives to third-party liability insurance have also been advanced such as robot-related liability stocks (Huttunen et al. 2010, p. 8), and first-party insurance where the victims instead of manufacturers take out insurance (Calo 2011, p. 611, this suggestion is confined to the manufacturers of open robotic platforms for the actions and improvements of third parties. Calo also adds "The immunity could eventually sunset and be supplemented by a market for consumer robot insurance" at 611).
} 
the risk. ${ }^{55}$ Probabilities of accidents by robotics may not always be easily estimated given the scientific uncertainty surrounding them, which will in turn cause difficulties for insurers in setting fairly charged premiums. Particularly with respect to 'emergent behaviours' of robotics, i.e. "modes of behaviour which were not predicted by the designer but which arise as a result of unexpected interactions among the components of the system or with the operating environment" ${ }^{56}$ the fundamental query for the insurers is how they will be placed to charge fair premiums where robots act in ways not even predictable for their programmers and trainers. This type of concern about smart robots which does not arise in the motor liability context would beg the question of whether other tools such as risk-sharing between operators ${ }^{57}$ that is adopted particularly in respect of risks where knowledge of probabilities is limited, would be a more suitable option. ${ }^{58}$ In the light of the foregoing, even if a preference is expressed in favour of a mandatory protection scheme, this should perhaps not be confined to compulsory liability insurance, ${ }^{59}$ given that 'emergent behaviours' that may gradually become an area of concern in respect of predictability of robot actions would substantially make it difficult for insurance markets to offer affordable premiums.

Compulsory insurance is usually implemented as a solution to risks that would pose great danger to third parties, and it can therefore be argued that as the level of risks posed by different types of robots will not be identical, compulsory insurance may only be required and necessary for those robots that present a high level of risk of damage. ${ }^{60}$ For instance, care robots would be more likely to pose a greater risk of bodily injury or death to third parties compared to robot toys, and whether the latter category should be subject to a compulsory insurance regime needs to be carefully thought through. In carrying out an impact assessment as to whether imposing compulsory insurance is necessary and justified in the context of robotics, circumstances such as the level of autonomy and predictability of the robot's behaviour, human presence in the environment where the robot operates, robot's physical capabilities and its connection with the environment may be taken into consideration. ${ }^{61}$ However reason would dictate that due regard should also be had to whether

\footnotetext{
${ }^{55}$ Richardson (2002), p. 296.

${ }^{56}$ A term used in Arkin (1998), as mentioned in D6.2 Guidelines on Robotics, p. 23.

${ }^{57}$ Such as in the case of Protection \& Indemnity Clubs whereby the shipowners contribute into a pool with the payment of 'calls' (premiums) and thereby form a risk-sharing tool to cover their liabilities against third parties.

${ }^{58}$ Skogh (1998), pp. 253-256.

${ }^{59}$ Summary of the public consultation on the future of robotics and artificial intelligence (AI) with an emphasis on civil law rules, available at http://www.europarl.europa.eu/cmsdata/130181/publicconsultation-robotics-summary-report.pdf (last accessed, 2 November 2018) where a survey among stakeholders resulted in the finding that a majority thereof were not in favour of establishing an obligatory insurance scheme for damages caused by autonomous robots, nor of establishing a compensation fund.

${ }^{60} \mathrm{~A}$ similar view was expressed in Huttunen et al. (2010), p. 5.

${ }^{61}$ Huttunen et al. (2010), pp. 5-7.
} 
insurance markets will easily accommodate a policy decision in favour of compulsory insurance. Oftentimes, developed and sufficiently large markets that are well equipped are required to cope with the demands of policyholders and third parties, and it would appear that the uncertainties surrounding robotics as well as different market characteristics in the EU are far from being reassuring in this regard.

\subsection{Connection Between Strict Liability and Compulsory Insurance}

The Product Liability Directive which would be likely to apply in establishing the smart robot producers' liability for third party damages ${ }^{62}$ establishes a strict liability regime. ${ }^{63}$ There may be strong correlations between strict liability and the requirement of compulsory insurance which has also been showcased in several jurisdictions through the introduction of compulsory insurance for liabilities occurring without fault. ${ }^{64}$ From the 'insolvency' perspective, the injurer under a fault-based liability scheme would face such a risk once the costs of care would exceed its wealth, whereas a problem of underdeterrence would arise under strict liability as soon as the damage exceeds the injurer's wealth. ${ }^{65}$ This latter situation would constitute one of the grounds for requiring compulsory insurance against the risk of underdeterrence by the injurer and accordingly that of the externalisation of costs. ${ }^{66}$ A further justification for introducing compulsory liability insurance where strict liability applies may lie in that this could enhance incentives to reduce risk $^{67}$ which, in the context of producers of smart robots, could translate into incentivising the increase of safety levels of the products. Therefore, an analysis of whether the strict liability of producers under the Product Liability Directive should be complemented by a compulsory insurance scheme would need to be carried out to identify the advantages and drawbacks of such a policy decision. ${ }^{68}$

Product liability is an area where although strict liability is established, no general duty to take out insurance is imposed-the Product Liability Directive does not

\footnotetext{
${ }^{62}$ Unless a policy decision is made to the effect of drafting another instrument particularly aimed at covering the liability of producers of smart robots.

${ }^{63}$ For the view that setting the standard of liability as strict liability before a level of sophistication is reached in respect of products can have counter effects on product innovation in the European Union, see Palmerini et al. (2016), p. 83.

${ }^{64}$ Rubin (2016), p. 44; Cousy (2016), pp. 80-81.

${ }^{65}$ Faure (2006), p. 156.

${ }^{66}$ Faure (2006), p. 156.

${ }^{67}$ Shavell (2000), p. 178.

${ }^{68}$ Not all liability regimes applicable in the instruments requiring a duty to take out financial security currently in force in the European Union are based on strict liability. The view that favours that strict liability should be complemented by a compulsory insurance system would evidently not connote that fault-based liability may not be.
} 
compel manufacturers putting their products into circulation within the European Union to take out insurance cover against potential third party claims. There is a large number of producers operating in the EU which are covered against strict liability arising from the Product Liability Directive under general insurance contracts (product liability insurance can be provided as a sub-section or endorsement of a combined public liability policy) with a considerable number of producers not even being insured against this risk. ${ }^{69}$ The foregoing being the case, sectoral legislation applicable to the producers of certain products may impose a duty to provide financial security, a recent example of which appears in the Medical Devices Regulation. $^{70}$

There may be several policy reasons for establishing strict liability, such as encouraging necessary incentives for investing in product safety; however to what extent this suggestion would prove right is controversial on the ground that it might rather persuade producers in purchasing insurance for matters outside their control. ${ }^{71}$ Moreover, even where compulsory insurance is introduced, liability insurers will provide compensation to third party victims only where the victims are successful in proving that the product causing their loss was defective, and that there was a causal connection between the defect and the loss. It has already been acknowledged that these two instances constitute $53 \%$ of the cases where a third party claim was rejected due to their failure in discharging the burden of proof. ${ }^{72}$ It would not be a fallacy to anticipate that this burdensome process would likely to be worsened in disputes involving robotics. Achieving the aim of protecting the victims may therefore lie in addressing this problem first, before a policy decision favouring the introduction of compulsory insurance can be made. ${ }^{73}$ One should also not lose sight

\footnotetext{
${ }^{69}$ Only $22 \%$ of the enterprises are covered against strict liability arising from the Product Liability Directive under a product liability insurance contract, with $57 \%$ of the enterprises having a general insurance contract covering, inter alia, the product liability risks; and $21 \%$ of the enterprises are not covered against these risks under any insurance contract, see The Final Report on the Evaluation of Council Directive 85/374/EEC, p. 16 fn 60.

${ }^{70}$ Regulation (EU) 2017/745 of the European Parliament and of the Council of 5 April 2017 on medical devices, amending Directive 2001/83/EC, Regulation (EC) No 178/2002 and Regulation (EC) No 1223/2009 and repealing Council Directives 90/385/EEC and 93/42/EEC. Art. 10 para 16 provides "Manufacturers shall, in a manner that is proportionate to the risk class, type of device and the size of the enterprise, have measures in place to provide sufficient financial coverage in respect of their potential liability under Directive 85/374/EEC, without prejudice to more protective measures under national law."

${ }^{71}$ Posner R (2007) Economic Analysis of Law. Walters Kluwer cited in Leenes et al. (2017), fn 54 where it is also suggested that loss of reputation stands as a better incentive towards investing in safety.

${ }^{72}$ The Final Report on the Evaluation of Council Directive 85/374/EEC, p. 23.

${ }^{73}$ Possibly by way of introducing a rebuttable presumption that the damage results from the defect, see Cauffman (2018), p. 5.
} 
of the potential effect of introducing compulsory insurance on producers that may accordingly be incentivised to pass the cost of the compulsory insurance premiums onto the consumers in the form of an increase in product prices.

Product liability is mentioned as merely part of the network of liability that the Resolution proposed where the owners and users of robotics as well as programmers were mentioned as potentially liable parties. The list provided is possibly only of illustrative nature and could also cover whomever is involved in the chain having either given instructions to the robots or trained them. As much as the standard of liability of producers is relatively clear given the Product Liability Directive, whether the liability of the foregoing parties will be strict or fault-based is yet to be identified. In either case, the standard of liability established will be required to be adequate in addressing also robots' 'emergent behaviours'.74 Determining the standard of liability is likely to require an analysis of the rules governing liability under the respondeat superior principle, ${ }^{75}$ liability for the acts of children ${ }^{76}$ and of animals, ${ }^{77}$ as liability for the acts of smart robots is regarded to be analogous to the foregoing. One substantial challenge of this initiative would however lie in the lack of harmonisation of the tort law rules applicable in the EU jurisdictions. $^{78}$

\subsection{The 'Development Risk' Defence}

Under the Product Liability Directive, manufacturers are not liable if they prove "that the state of scientific and technical knowledge at the time when the product was put into circulation was not such as to enable the existence of the defect to be discovered". 79 It has been argued in several instances whether unintended behaviour of smart robots resulting in a damage to third parties may constitute a 'defect' within the meaning of the Directive, and whether the development risk defence could relieve manufacturers of smart robots in a great number of cases on the ground that robotics technology is constantly evolving. ${ }^{80}$ Before assessing the potentials for this suggestion, a general overview of the defence will be provided with a focus on

\footnotetext{
${ }^{74}$ D6.2 Guidelines on Robotics, p. 23.

${ }^{75}$ Hubbard (2014), pp. 1803-1872.

${ }^{76}$ Chopra and White (2011), pp. 128-130.

${ }^{77}$ Kelley et al. (2010), pp. 1861-1871.

${ }^{78} \mathrm{~A}$ comparative research project was conducted by a group of experts ('European Group on Tort Law') with a view to achieve a certain level of harmonisation among the tort law rules applicable in European Union countries. This initiative gave rise to the 'Principles of European Tort Law' (see European Group on Tort Law 2005) which may constitute a primary source of inspiration for approximating the EU Member States' tort laws.

${ }^{79}$ Art. 7(e). This defence is known as the 'development risk defence'.

${ }^{80}$ Courtois (2016), p. 289; Machnikowski (2016), pp. 17-110.
} 
the judicial approach to the defence, the branches of industry that most rely thereon, as well as the frequency of such reliance thus far.

The defence aims at striking a fair balance between fostering innovation within Europe and the protection of consumers, ${ }^{81}$ yet the Member States were given the option not to adopt the defence in their national instruments implementing the Directive. ${ }^{82}$ The practice on derogation accordingly differed among the Members States: Luxembourg and Finland transposed the Directive by adopting the derogation without limitations whereby the derogation was made applicable to all categories of products and producers. ${ }^{83}$ Hungary, in turn, adopted the Directive together with the development risk defence, which however does not apply in respect of medical products. ${ }^{84}$ In Spain, manufacturers cannot invoke this exemption in respect of medical products and food products where the latter are produced for human consumption. ${ }^{85}$ Moreover in France, the defence may not be relied upon where the damage is caused by an element of the human body or by products derived therefrom. ${ }^{86}$ These national restrictions are accompanied by a strict interpretation of the defence by the Court of Justice of the European Union (CJEU) which confirmed that the defence would apply where the producer could prove that the objective state of knowledge that is at 'the most advanced level and not restricted to the relevant industrial sector' at the time the product was put into circulation was not such as to allow the discovery of defect in the product. ${ }^{87}$ The defence is also not based on the unavoidability of the defect, but on the accessibility of knowledge by the producer. ${ }^{88}$ It may be relatively clear that a confidential study that has not yet been published may not satisfy the accessibility test, however a more elaborate question may be whether a study published in a single country only in the local language could do so. ${ }^{89}$ The defence is notably the most recurring liability exemption which has been triggered in $4 \%$ of the cases $;{ }^{90}$ the foregoing hurdles in invoking the defence nevertheless ended up in a minimal number of cases where the producers were successful.

\footnotetext{
${ }^{81}$ The Final Report on the Evaluation of Council Directive 85/374/EEC provides that the removal of the development risk clause would not be beneficial for innovation in the EU according to the desk research conducted, see $\mathrm{p}$. xvii.

${ }^{82}$ Art. 15 of the Product Liability Directive.

${ }^{83}$ The Final Report on the Evaluation of Council Directive 85/374/EEC, p. 16.

${ }^{84}$ The Final Report on the Evaluation of Council Directive 85/374/EEC, p. 16.

${ }^{85}$ The Final Report on the Evaluation of Council Directive 85/374/EEC, p. 16.

${ }^{86}$ Code Civil Français Art 1245-11: "Le producteur ne peut invoquer la cause d'exonération prévue au $4^{\circ}$ de l'article 1245-10 lorsque le dommage a été causé par un élément du corps humain ou par les produits issus de celui-ci."

${ }^{87}$ ECJ C-300/95, Commission v UK [1997] ECR I-2649, paras. 26-27.

${ }^{88}$ A v National Blood Authority [2001] 3 All ER 289.

${ }^{89}$ Wuytz (2014), p. 31.

${ }^{90}$ According to the Final Report on the Evaluation of Council Directive 85/374/EEC the development risk clause was invoked more often in Italy, France, Hungary and Belgium, p. 24.
} 
On the one hand, the proponents of this defence could argue that removing it would endanger innovation, ${ }^{91}$ however the successful reliance thereon could risk that consumers are left without compensation. This would accordingly result in a protection gap for consumers and a potential consequent recourse to social security systems established in Member States; hence a plausible risk-sharing scheme as regards the scientifically unknown risks is necessary and unavoidable. ${ }^{92}$ It is noteworthy that the problem of no compensation in the event where the development risk clause is successfully invoked will arise particularly in schemes where insurance is taken out for products other than automated vehicles, where a system is implemented whereby motor insurers will be the ultimate payers of claims where the manufacturers or their insurers rely upon the development risk clause so as to exonerate from liability. ${ }^{93}$ Where no such scheme is in place and the clause is successfully triggered, third party victims will not be able to be compensated by insurers. Consistent successful reliance on the development risk defence by producers could also disincentivize a risk-averse producer to take out liability insurance, as its purchase decision would be made based on its assets in relation to potential liabilities, the likelihood of these liabilities and the degree of risk aversion. ${ }^{94}$

Whereas an option available is to remove the application of the clause in respect of AI and robotics amid concerns that third parties may be left uncompensated, chances are that this could raise product liability insurance premiums which may accordingly be passed onto consumers through price increases. This could also have a domino effect on R\&D expenses whereby companies could possibly economise thereon and ultimately increase safety risks. Where, contrary to the proposal of the Resolution, product liability insurance is not compulsory and in theory no reliance is permitted for producers of robotics on the clause, it is submitted that it would be fairly difficult for producers to find a market to insure their development risks, given that they are rare and often result

\footnotetext{
${ }^{91}$ European Commission, Report from The Commission to the European Parliament, the Council and the European Economic and Social Committee, Fourth Report on The Application of Product Liability Directive, COM (547), 2011, p. 9. The Final Report on the Evaluation of Council Directive 85/374/EEC, pp. 82-83 also provides “....contrasting positions are held by businesses responding to the CATI survey with regard to removing the development risk clause: this possibility is viewed favourably by $43 \%$ of large firms, while the largest share of medium-sized firms (38\%) thinks this removal would be disadvantageous. Small firms tend to think that this removal would be neutral (33\%) or even disadvantageous (31\%)."

${ }^{92}$ This view was expressed regarding connected and automated vehicles in Mapping the Cost of Non-Europe 2014-2019 available at http://www.europarl.europa.eu/EPRS/EPRS_STUD_603239_ Mapping_fourth-edition-FINAL.pdf (last accessed, 10 November 2018), at p. 149.

${ }^{93}$ The UK Automated and Electric Vehicles Act 2018 which received the Royal Assent on 19 July 2018 adopted this approach, see 'Pathway to driverless cars: Consultation on proposals to support Advanced Driver Assistance Systems and Automated Vehicles, Government Response' available at https://assets.publishing.service.gov.uk/government/uploads/system/uploads/attachment_data/file/ 581577/pathway-to-driverless-cars-consultation-response.pdf (last accessed, 2 November 2018), para 3.15 .

${ }^{94}$ Shavell (2000), p. 174.
} 
in severe damages. ${ }^{95}$ On the other hand, a system where the producers can rely on the development risk defence and are required to take out product liability insurance would be likely to increase the moral hazard of producers who would be less incentivised to observe safety standards. In such a system, there would be a risk that third party victims may not be compensated unless the specific provisions making the insurance compulsory prohibit insurers to rely on the producers' defences.

\subsection{Deductibles}

A tool adopted for controlling the behaviour of insureds is, among others, to agree deductibles in insurance policies. In first-party insurance, deductibles serve the function of eliminating some claims altogether where they do not reach the figure stated in the deductible clause; however in liability insurance they prevent third party victims from claiming losses not reaching the deductible limits from insurers, ${ }^{96}$ who are then left with the option of seeking them from the liable parties themselves. In theory, insurers may impose a high deductible in a product liability insurance policy to evade claims not reaching the stated limits and incentivise producers to adopt safety measures given that the risk of those claims would have been allocated to them. This could however create an unnecessary hurdle for third parties particularly where the type of loss suffered is death or personal injury that exceeds the deductible. In such a case, third parties would have to claim both against the producer and the insurer (should they have a right of direct action against insurers) for full compensation.

Further complications in addition to the above may also arise due to the differences in the wording used in deductible clauses for aggregating losses. In product liability policies, deductibles are often written either on per-occurrence or per-annum basis. Where the latter may be relatively straightforward in providing for the maximum amount to be borne by the claimant within a single policy year, the former would give rise to considerable controversy because of the multifarious meanings that can be attached to 'occurrence'. ${ }^{97}$ For the purposes of damages arising from the acts of defective robots, the fundamental query would lie in whether (a) the defect that results in several harmful acts causing separate damages; or (b) each harmful act of the robot arising from the same defect causing separate damages; or (c) each separate damage, would qualify as 'occurrence'. The interpretation of the term 'occurrence' would accordingly dictate whether the deductible would apply to the entirety of damages arising from the same defect, or whether a different deductible would apply for each act

\footnotetext{
${ }^{95}$ Fondazione Rosselli, Analysis of the Economic Impact of the Development Risk Clause as provided by Directive 85/374/EEC on Liability for Defective Products - Final Report, p. 71.

${ }^{96}$ Schwartz (1990), pp. 316-317.

${ }^{97}$ In Caudle v Sharp [1995] C.L.C. 642, 648 it was enunciated by Evans LJ that for the purposes of a reinsurance contract "the occurrence out of which a claim arises, for loss suffered by the original insured, such as storm damage, flood damage or the like, or in the case of professional indemnity losses, the negligent act or omission of the insured" (emphasis added).
} 
of the robot that results in damages. Due to the risk that varying meanings can be allocated to this wording in different European Union jurisdictions, unintended consequences in the treatment of third party victims may arise..$^{98}$

However, where insurance is mandatory, deductibles may not be relied upon by insurers. The Motor Insurance Directive, for instance, dealt with this particular issue by providing that insurers are not allowed to require an injured party ${ }^{99}$ to bear an excess. ${ }^{100}$ A similar provision may also be adopted in the context of product liability policies for personal injury damages arising from a defect in the robotics manufactured to the effect that the insurers would not have the right to rely on contractual provisions — such as deductibles — to deny third party claims.

Property damages suffered by third parties would however be subject to a different system than personal injuries'. The Product Liability Directive states that producers are not liable for property losses suffered by product users which do not exceed $€ 500$, provided that the item causing third party loss is ordinarily intended for private use and was mainly used by the third party as such. ${ }^{101}$ This figure was either interpreted as a threshold whereby losses not exceeding the figure would not be claimed, or as an excess that would have to be deducted from the indemnity. ${ }^{102}$ In both cases, unless the property loss exceeds the figure of $€ 500$, no liability of the producer-and accordingly of the insurer-will arise. Accordingly, no compensation will be available for the third party. This situation will further be accentuated where the limit is increased in respect of property losses arising from the use of new technologies ${ }^{103}$ which will potentially leave out a great number of small claims arising from the acts of robotics that will have to be borne by the victims. It is also noteworthy that where the property damage exceeds both $€ 500$ and the policy deductible, third parties would have to claim both against the producer (for the difference between $€ 500$ and the policy deductible) and against the insurer (for the excess of the policy deductible).

\footnotetext{
${ }^{98} \mathrm{An}$ initiative to deal with the inconsistencies of different jurisdictions' approaches to aggregation wordings in the reinsurance context is undertaken by the drafting committee of the Principles of Reinsurance Contract Law (PRICL). Inspired by the work of the Project group 'Restatement of European Insurance Contract Law' that had resulted in the publication of the Principles of European Insurance Contract Law (PEICL) in 2009 (which was later on revised and was made public again in 2015), the aim of the committee is to provide a restatement of global reinsurance contract law principles.

${ }^{99}$ Defined as "any person entitled to compensation in respect of any loss or injury caused by vehicles" (emphasis added) and in theory, would also apply to third parties suffering property damages. However, see below the discussion on the role of deductibles in insurance policies covering the liability of producers for property damage where the Product Liability Directive would govern the liability of the producer.

${ }^{100}$ Art. 17.

${ }^{101}$ Product Liability Directive Art 9(b)(i) and (ii).

${ }^{102}$ The Final Report on the Evaluation of Council Directive 85/374/EEC, pp. 16-17. It is also noteworthy that in respect of property damage suffered by victims that is caused by vehicles stolen or obtained by violence, the Motor Insurance Directive grants an option to Member States to fix an excess of not more than $€ 250$ to be borne by the victim.

${ }^{103}$ See The Final Report on the Evaluation of Council Directive 85/374/EEC, p. xiii.
} 


\subsection{Precautionary Measures}

Another option available to insurers for controlling the moral hazard of producers is to monitor their behaviour through policy clauses such as precautionary measures. ${ }^{104}$ The rationale behind monitoring such behaviour rests upon the fact that the liability of the producer would trigger the insurers' own liability and any action taken towards decreasing the likelihood of this trigger would alleviate the insurers' risk. In the general context of product liability, however, it may be difficult for insurers to achieve this aim due to several reasons. Firstly, given that for the insurer's liability to arise the product would need to be defective within the meaning of the Product Liability Directive, the insurers' monitoring would have to aim to reduce the occurrence of defects. How this can be ensured is, though, far from being an easy task: defects are often developed during the production stage, however product liability insurance would often be purchased before the product is put into circulation, i.e. after the product has been developed. Accordingly, any steps towards monitoring the behaviour of the producer would merely have ex-post effect. Secondly, a clause seeking to monitor the behaviour of the producer by reference to compliance with the General Product Safety Directive ${ }^{105}$ (GPSD—which operates ex-ante) may ensure a certain level of control; yet would arguably not grant sufficient protection for insurers: Non-compliance with safety requirements enshrined in the Directive would not necessarily result in the defectiveness of the product, or, from the insurers' perspective, compliance therewith would not in all circumstances prevent defect. Moreover, it is available to producers to allocate their risk of liability as well as expenses arising from recalling their defective products from the market onto liability insurers under 'product recall insurance'. ${ }^{106}$ This could further disincentivise a producer having this type of cover from adopting a higher level of care in complying with the GPSD.

The above suggests that insurers would frequently stipulate precautionary measures to have an ex-post control, yet this arguably would not prove entirely useful for increasing product safety incentives that would have mostly occurred at the product development stage. An exception to this may however occur where a potential liability can be avoided if the producer is made aware that the safety of the product is called into question and acts to remedy the product deficiencies by for instance issuing additional user instructions. This latter possibility exists in the Medical

\footnotetext{
${ }^{104}$ These are also known as 'warranties' in certain jurisdictions such as the United Kingdom.

${ }^{105}$ Directive 2001/95/EC of the European Parliament and of the Council of 3 December 2001 on general product safety.

${ }^{106}$ This type of insurance is usually purchased separately than product liability insurance. The latter cover is sometimes offered as part of companies' commercial general liability insurance whereas the former is often not.
} 
Devices Regulation ${ }^{107}$ which imposes a duty to provide financial security for manufacturers of devices within the scope of the Regulation. ${ }^{108}$

Another problem that precautionary measures may pose is that the rules applicable thereto depends on the law governing the insurance contract. Accordingly, the control of moral hazard by insurers will depend on what consequences are attached to the breach of the precautionary measures as per the wording of the relevant policy, and any legislative rules that would be applicable to the clauses. The lack of harmonisation of the rules applicable to precautionary measures therefore stands as a hurdle which could obstruct the very aim of precautionary measures, i.e. to achieve deterrence: in jurisdictions where such clauses are strictly regulated and can be invalidated relatively easily, insurers would have to carefully draft their clauses so as not to lose the protection sought by their inclusion in the policies. Otherwise this would lead to the provisions not being applicable and lifting off the pressure on producers for observing safety standards. The diverse regulation of rules applicable to precautionary measures may further endanger the proportionate distribution of demands for product liability insurance among the insurance markets. This would notably beg the question of whether initiatives towards the harmonisation of insurance contract law principles such as the Principles of European Insurance Contract Law (PEICL) ${ }^{109}$ could be an appropriate solution to this problem. ${ }^{110}$

Another issue is to what extent precautionary measures would disturb victims' rights against insurers where a right of direct action is granted to them for losses suffered from defective products. The obvious legal problem would lie in whether or not the outcome of any breach of precautionary measure by the producer (e.g. termination of the contract by the insurer, non-payment of any subsequent loss etc.) could be raised as a defence against the third party victim. As mentioned in the previous paragraph, the answer to this query would also depend on national law rules unless it is regulated at the EU level to avoid the risk of no compensation of third parties. ${ }^{111}$ Such regulation would naturally be in the favour of victim protection, yet it could also be the subject of criticism by economists who would stress that

\footnotetext{
${ }^{107}$ Regulation (EU) 2017/745 of the European Parliament and of the Council of 5 April 2017 on medical devices, amending Directive 2001/83/EC, Regulation (EC) No 178/2002 and Regulation (EC) No 1223/2009 and repealing Council Directives 90/385/EEC and 93/42/EEC.

${ }^{108}$ Art. 10.16 provides "Manufacturers shall, in a manner that is proportionate to the risk class, type of device and the size of the enterprise, have measures in place to provide sufficient financial coverage in respect of their potential liability under Directive 85/374/EEC, without prejudice to more protective measures under national law."

${ }^{109}$ The Principles of European Insurance Contract Law (PEICL) are a set of model rules which aims at establishing a common insurance contract law sphere across the European Union.

${ }^{110}$ Articles 4:101-4:103 contain provisions applicable to precautionary measures.

${ }^{111}$ PEICL Art. 15:101(2) provides "As against the victim, the insurer may raise defences available under the insurance contract unless prohibited by specific provision making the insurance compulsory. However, the insurer is not entitled to raise any defence based upon the conduct of the policyholder and/or the insured after the loss." This would connote that any breach of precautionary measure by the producer before any loss or damage to the victim has occurred may be relied on by the insurers as a defence against the victim.
} 
the main aim of insurance is to cure the risk of underdeterrence and to remove risk from the injurer, ${ }^{112}$ as opposed to principally protecting the victims.

\section{Potential Limits to the Protection of Third Parties in the Insurance Framework}

One of the policies behind the proposal of a compulsory insurance scheme for producers of smart robots was to ensure a higher level of protection for third party victims. This aim could be achieved to a greater extent through the introduction of a direct right of action against insurers. The below sections elaborate how the absence of a right of direct action against insurers or the Fund, along with how claims-made policies may operate in the insurance framework against this aim.

\subsection{Lack of a Right of Direct Action Against Insurers}

The right of direct action means that a party suffering injuries or damage for which another party is liable may bring an action against the liable party's insurer directly without having to sue that party. This right is usually granted to the victims in cases where there is a duty to take out insurance; yet where this is not required at the EU level, recourse would have to be made to the national law governing the insurance contract which may or may not grant it. Within the EU, third party victims have a right of direct action under the Motor Insurance Directive, ${ }^{113}$ however this is not expressly provided for under the Regulation on Insurance Requirements for Air Carriers and Aircraft Operators. ${ }^{114}$ At the international level, passengers may also bring a direct action against the insurers of carriers undertaking the carriage of passengers by sea under the Athens Convention as amended by the 2002 Protocol. $^{115}$

\footnotetext{
${ }^{112}$ Faure (2006), p. 158.

${ }^{113}$ Art. 18.

${ }^{114}$ Regulation (EC) No 785/2004 of 21 April 2004 on insurance requirements for air carriers and aircraft operators, see also Directive 2009/20/EC of the European Parliament and of the Council of 23 April 2009 on the insurance of shipowners for maritime claims.

${ }^{115}$ Athens Convention relating to the Carriage of Passengers and their Luggage by Sea, 1974 as amended by the Protocol of 2002 to the Convention has been made applicable within the European Union through the Regulation (EC) No 392/2009 of the European Parliament and of the Council of 23 April 2009 on the liability of carriers of passengers by sea in the event of accidents. Art. 3(1) of the Regulation provides that the rules on insurance will be governed, inter alia, by 3 to 16 of the Convention as amended by the 2002 Protocol. Art. 4bis(10) of the Convention provides the right of direct action against insurers which will be applicable within the EU provided that the passenger claim is within the scope of application of the Regulation that is provided under Art. 2 of the Regulation.
} 
The fact that recourse would have to be made to national laws where the EU legislative instruments are silent in this regard, risks of giving rise to inconsistencies in third party protection where some jurisdictions allow such direct actions in all cases ${ }^{116}$ whereas others do it to a more restricted basis. ${ }^{117}$ For a harmonised regime in the EU that is sought to be protective of third party victims, whether the right of direct action must be established in respect of both product liability and civil liability claims would need to be elaborated before the instruments regulating the insurance of robotics are implemented. Where the PEICL govern the insurance contract however, third parties would automatically benefit from the option of claiming directly against the liability insurers where the relevant criteria under Art. 15:101 are fulfilled.

PEICL would apply "where parties, notwithstanding any limitations of choice of law rules under private international law, have agreed that their contract shall be governed by it". ${ }^{118}$ Where such agreement is made in favour of the application of PEICL, the provisions take effect in their entirety and the parties are not allowed to exclude the application of particular provisions. ${ }^{119}$ It is also noteworthy that where contracts are governed by PEICL, no recourse to national law to restrict or to supplement the provisions of the PEICL is allowed with respect to the branches of insurance covered by PEICL, ${ }^{120}$ i.e. liability insurance, among others. Their scope of application also cover insurance contracts which are concluded in accordance with a duty to take out insurance. ${ }^{121}$ The aim of the PEICL was not to unify compulsory insurance law, yet to offer a uniform model law for insurance contracts. ${ }^{122}$ An insurance contract governed by PEICL would therefore be subject to the provisions of PEICL on compulsory insurance, and would only be deemed to have satisfied the requirements pertaining to the duty to take out insurance if it complied with the specific provisions imposing the obligation ${ }^{123}$ under the Community law or the law of the Member States. The latter laws will therefore prevail in case of any potential dispute between PEICL and the latter, ${ }^{124}$ and so long as the PEICL comply with the

\footnotetext{
${ }^{116}$ E.g. French Code des Assurances Art. L124-3 provides "Le tiers lésé dispose d'un droit d'action directe à l'encontre de l'assureur garantissant la responsabilité civile de la personne responsable."

${ }^{117}$ For a list of the relevant rules adopted in the European Union Member States limiting the right of direct action to certain circumstances, see Basedow et al. (2016), p. 302 fn 42.

${ }^{118}$ Art. 1:102.

${ }^{119}$ Art. 1:102. This provision is subject to Art. 1:103 which provides a list of the mandatory articles which may not be derogated from; derogation from all other provisions may be allowed merely where such derogation would not prejudice the interests of the policyholder, insured or beneficiary. ${ }^{120}$ Art. 1:105.

${ }^{121}$ Art. 16:101 provides that the PEICL may be chosen by the parties of an insurance contract whereby an obligation to insure derives from the Community Law, the law of a Member State or the law of a Non-Member State to the extent allowed by the law of that State.

${ }^{122}$ Heiss (2016), pp. 309-310.

${ }^{123}$ Art. 16:101(2).

${ }^{124}$ Heiss (2016), p. 311.
} 
relevant Community laws or national law rules on compulsory insurance, there would be no need of recourse to these laws. ${ }^{125}$

Given that the rules enshrined in the PEICL governing liability insurance seek to offer a high level of victim and policyholder protection, ${ }^{126}$ it is expected that the provisions of the PEICL will oftentimes comply with the Community laws or Member States laws on compulsory insurance. In view of the foregoing, PEICL would be a fairly relevant model law particularly in respect of their rules on direct action of the victim against the insurer which is granted provided that either (a) the insurance is compulsory, ${ }^{127}$ or (b) the policyholder or insured is insolvent, ${ }^{128}$ or (c) the policyholder or insured has been liquidated or wound up, ${ }^{129}$ or (d) the victim has suffered personal injury, ${ }^{130}$ or (e) the law governing the liability provides a direct claim. ${ }^{131}$ The valid incorporation of the PEICL into the insurance contract would be sufficient for this right to be applicable in respect of third party claimants against insurers if it is not already found in a legislative instrument that will govern the liability insurance for the acts of smart robots.

In addition to this right, further protection of third parties may also be achieved where the law governing the insurance contract contains rules requiring businesses providing insurance services to make payment within a given period of time or compensate losses arising from late payment. ${ }^{132}$ Third parties having a right of direct action could accordingly sue the insurer and be compensated in reasonable time.

\subsection{Lack of a Right of Direct Action Against the Compensation Fund}

The suggestions made in the Resolution and Report were to the effect that the Commission should consider supplementing the compulsory insurance by a fund where the latter would serve the twin purposes of guaranteeing compensation to third parties where no insurance cover is in place for the acts of robots, ${ }^{133}$ as well as to collect investments and donations made in respect of smart autonomous robots. ${ }^{134}$

\footnotetext{
${ }^{125}$ Heiss (2016), p. 312.

${ }^{126}$ See for instance Art. 15:101 on direct action against insurers and Art. 14:106 on bonus-malus systems respectively.

${ }^{127}$ Art. 15:101(1)(a).

${ }^{128}$ Art. 15:101(1)(b).

${ }^{129}$ Art. 15:101(1)(c).

${ }^{130}$ Art. 15:101(1)(d).

${ }^{131}$ Art. 15:101(1)(e).

${ }^{132}$ PEICL Art. 6:104 and 6:105. As provisions applicable to all contracts included in PEICL, they would also be relevant for liability insurance contracts.

${ }^{133}$ The Report, para 31(b); the Resolution, para 59(b).

${ }^{134}$ The Report, para 31(b).
} 
Exploring the feasibility of establishing a compensation fund that would operate as complementary to a private insurance scheme would require an assessment of, including but not limited to, the below points:

- Whether the fund should cover all categories of smart robots or be categoryspecific (this part of the study would require an analysis of the key categories of smart robots that are more prompt to cause a major loss), ${ }^{135}$

- Whether it should operate at the EU level or be country-specific,

- Whether it should respond where no insurance is in place, where the insurance is not adequate to cover the third party claim, or where the insurer is insolvent,

- Who should contribute to the fund and in what proportions (whether a percentage of the annual net sales revenue would be adequate),

- Whether the contributors to the fund should enjoy limited liability because of having made such contribution, ${ }^{136}$

- Whether the right to operate in the robotics sector should be made subject to the granting of a license whereby the licensing bodies would assess the financial capability of the applicant according to the financial security provided, ${ }^{137}$

- Whether the unspent surplus of contributions, if any, should be redistributed to the contributors to be allocated to reinforce safety measures.

Compensation or guarantee funds are found in several sectors as the addressee of third party claims other than the insurers of the liable parties, or the liable parties themselves. Funds established to compensate third party claims arising out of the adverse effects of pharmaceutical treatment, oil pollution, or motor accidents currently operate at national, regional or international level. ${ }^{138}$ Their exact function is usually determined by reference to the level of protection sought for the third party victims: supplementing the liability of the responsible party where the loss exceeds the party's limits of liability; and offering compensation where the responsible party succeeds to rely on an exclusion of liability, or where it fails to respond to the claim due to financial constraints such as insolvency, or where no insurance is in place for the liability in question. As much as compensation funds may operate as an 'insurer of last resort', they are separate entities than insurance undertakings, and provisions whereby the right of direct action is granted against insurers may not necessarily

\footnotetext{
${ }^{135}$ The Resolution, para 59(d).

${ }^{136}$ The Resolution, para 59(c).

${ }^{137}$ As in the Directive 2013/30/EU of the European Parliament and of the Council of 12 June 2013 on safety of offshore oil and gas operations and amending Directive 2004/35/EC ('Offshore Safety Directive') Art. 4(2)(c).

${ }^{138}$ For examples, see the Swedish Pharmaceutical Insurer that is financed, inter alia, by pharmaceutical and R\&D companies that respond to medication-related injuries of third party claimants; the Oil Pollution Compensation Fund (IOPC) established under the International Convention on the Establishment of an International Fund for Compensation for Oil Pollution Damage 1992 (the 'Fund Convention' 1992) and which supplements the regime introduced by the International Convention on Civil Liability for Oil Pollution Damage 1992; uninsured and untraceable drivers' funds established as per the Motor Insurance Directive.
} 
allow the exercise of such right against the funds. This has been pointed out ${ }^{139}$ in respect of the Motor Insurance Directive Art. 18 which establishes such right against the insurance undertaking, yet neither this article nor any other one under the Directive covers the right of direct action against the guarantee funds. In addition to whether third parties will be allowed to have a right of direct action against the insurers, whether they will be permitted to directly claim against the fund would also need to be carefully thought through.

\subsection{Claims-Made and Claims-Occurring Policies}

Imposing a duty to take out insurance on producers with the aim of granting maximum protection for third parties may not always work in the favour of the latter where the contractual dynamics between the policyholder and insurer are such that they rule out some third party claims altogether. One of the ensuing queries would therefore lie in what types of defences would be available to the insurers when faced with a direct action by the victims. Under the PEICL, the insurers can raise all the defences available to them under the policy that they could have otherwise raised against the policyholder unless this is prohibited by the laws imposing the duty to take out insurance. ${ }^{140}$ This being the case, no defence may be available to the insurers in respect of post-loss conduct of the policyholder ${ }^{141}$ on the ground that the right of direct action arises with the occurrence of loss, and may not be affected by any subsequent conduct of the policyholder. Among these possible defences, precautionary measures were covered above. ${ }^{142}$ The below is an overview of the impact of a policy written on claims-made or claims-occurring basis on third party protection.

As long as contractual flexibility permits and the relevant instruments imposing compulsory insurance do not regulate whether the relevant liability insurance policies should be made on loss occurring or claims-made basis, it may be argued that the intended level of safeguard may be difficult to achieve where a policy is written on claims-made basis. Such policies would entail a greater risk that the third party may not be compensated where, for instance, the claim was made at a time where there was no policy in place, or depending on the rules applicable to the contract, the cover was suspended. To the contrary, liability insurance policies on claimsoccurring basis will be more in favour of third party victims as they will respond

\footnotetext{
${ }^{139}$ Commission Staff Working Document Impact Assessment Accompanying the document Proposal for a Directive of the European Parliament and of the Council amending Directive 2009/103/ EC of the European Parliament and the Council of 16 September 2009 relating to insurance against civil liability in respect of the use of motor vehicles, and the enforcement of the obligation to insure against such liability, p. 128.

${ }^{140}$ Art. 15:101(2).

${ }^{141}$ Art. 15:101(2).

${ }^{142}$ See Sect. 3.5 above.
} 
even after the policy is cancelled or elapses, provided that the event giving rise to the claim occurs during the policy period regardless of when the claim is made. Claimsmade policies have been preferred particularly in respect of 'longtail' losses, i.e. where an injury or loss might not become manifest as soon as the act giving rise to it occurs. ${ }^{143}$ For instance in the context of robots, exercising under the instructions administered by a malfunctioning care robot $^{144}$ could gradually result in an injury over time. Considering that the use of care robots will exponentially arise in the upcoming years, this type of gradual damages may not be rare and the choice of claims-made policies in such circumstances may operate to the detriment of third party claimants.

Product liability insurance contracts can in theory be concluded on either basis and the domestic insurance markets' established practice in this regard will play a role. ${ }^{145}$ This may give rise to circumstances where third party claimants in some jurisdictions may have to bear the risks entailed with claims-made policies while claimants in other jurisdictions enjoy the relatively favourable claims-occurring based policies. Whether this danger of disparity should be averted through strict regulatory action by policy makers ${ }^{146}$ or whether insurers should merely be encouraged to write occurrence coverage might become a subject of debate in the near future. For consumer liability insurance contracts, the definition of 'insured event' in the PEICL is made by reference to the event which gives rise to the liability of the insured/policyholder whereby the insurers would be required to respond even if the victim suffered a loss subsequent to the end of the policy period. ${ }^{147}$ This rule is mandatory. ${ }^{148}$ For commercial and professional liability insurance contracts, however, the rule only operates by default and parties are otherwise free to contract on claims-made basis provided that the

\footnotetext{
${ }^{143}$ The problems suffered by insurers facing asbestos claims in the United Kingdom rested upon the issuance of policies on claims-occurring basis whereby the insurers had to respond to claims even decades after the policies had elapsed. This subsequently paved the way for the abandonment of 'claims-occurring' policies for 'claims-made' policies, see on this point Mildred (2001), p. 244.

${ }^{144}$ It was submitted in Robinson et al. (2014), p. 581 citing "Mann JA, MacDonald BA, Kuo I, Li X, Broadbent E (2014) People respond better to robots than computer tablets delivering healthcare instructions (in submission)": "Research has found that an advantage of robotic technologies over other technologies is that people are more motivated to follow instructions. One study found that people were more likely to perform relaxation exercises if the instructions were administered by a robot in comparison to a computer tablet [65]".

${ }^{145}$ For instance, although in the United Kingdom there may be a tendency towards insuring product liability on a claims occurring basis, insurers may prefer offering claims-made policies for high risk products to limit their exposure.

${ }^{146}$ See Abraham (1986), p. 59 for the view that as long as there is ignorance of the claims future, imposing on insurers the writing of claims occurrence coverage may result in that they act as speculators whereas they are actually risk spreaders.

${ }^{147}$ Art. 14:107(1) provides "The insured event shall be the fact giving rise to the insured's liability that occurred during the liability period of the insurance contract unless the parties to an insurance contract for commercial or professional purposes define the insured event with reference to other criteria such as the claim made by the victim."

${ }^{148}$ Basedow et al. (2016), p. 297.
} 
insurers are required to respond to claims not only occurring during the policy period, but also during an additional period of no less than five years. ${ }^{149}$ The application of the latter rule to product liability insurance policies would appear to be protective of third parties without disproportionately disturbing the freedom of contract, and may therefore be regarded as an optimum middle course.

\section{Conclusion}

As much as the policy reasons behind the introduction of compulsory insurance may be the protection of third parties and the objective of achieving a higher level of product safety, it is submitted that a rushed and premature initiative towards this goal would constitute a caveat for product innovation. The role accorded to insurance in this setting would therefore need to be minutely elaborated. This chapter sought to demonstrate that compulsory insurance may be a remedy rather than an obstruction in cases where no fundamental uncertainties surrounding the definition of risks exist; the insurance markets are sufficiently large and developed to cope with the demands of insureds; and the costs of compulsory insurance premiums are not unnecessarily high to the point that producers would prefer externalising this cost by increasing the product prices. In addition to the foregoing, regulatory initiatives should consider the issue of direct action against insurers and assess whether a harmonised regime exists in respect of what circumstances would give rise to such right, as well as whether a balance is struck between contractual freedoms and necessary interventions in the insurance sphere.

A scheme not observant of the above may have an unintended effect of channelling producers to distribute their products outside of the European Union where no compulsory insurance would be required, which may in turn disturb the variety of robotics available in the EU market. This may significantly undermine the initial policy-making objective behind the introduction of compulsory insurance, i.e. ensuring the protection of third parties and product safety without hampering innovation of robotics within the EU.

\section{References}

\section{Books}

Abraham KS (1986) Distributing risk: insurance, legal theory, and public policy. Yale University Press

Arkin RC (1998) Behavior-based robotics. MIT Press, Cambridge

${ }^{149}$ Art. 14:107(2). 
Basedow J, Birds J, Clarke M, Cousy H, Heiss H, Loacker L (2016) Principles of European Insurance Contract Law, 2nd exp. edn. Ottoschmidt

Chopra S, White LF (2011) A legal theory for autonomous artificial agents. The University of Michigan Press

European Group on Tort Law (2005) Principles of European Tort Law. Text and commentary. Springer, Wien, New York

Mildred M (2001) Product liability: law and insurance. Informa Law from Routledge

\section{Book Chapters}

Cousy H (2016) Compulsory liability insurance in Belgium. In: Fenyves A, Kissling C, Perner S, Rubin D (eds) Compulsory liability insurance from a European perspective. De Gruyter, pp $45-81$

Faure MG (2016) Compulsory liability insurance: economic perspectives. In: Fenyves A, Kissling C, Perner S, Rubin D (eds) Compulsory liability insurance from a European perspective. De Gruyter, pp 319-341

Heiss H (2016) Compulsory liability insurance in the Principles of European Insurance Contract Law (PEICL). In: Fenyves A, Kissling C, Perner S, Rubin D (eds) Compulsory liability insurance from a European perspective. De Gruyter, pp 301-317

Machnikowski P (2016) An analysis of the state of the art in the era of new technologies. In: Machnikowski P (ed) European product liability. Intersentia, pp 17-110

Rubin D (2016) Compulsory liability insurance in Austria. In: Fenyves A, Kissling C, Perner S, Rubin D (eds) Compulsory liability insurance from a European perspective. De Gruyter, pp $17-44$

\section{Articles}

Boddington P (2017) EPSRC principles of robotics: commentary on safety, robots as products, and responsibility. Connect Sci 29(2):170-176

Calo MR (2011) Open robotics. Maryland Law Rev 70:571-613

Cauffman C (2018) Robo-liability: the European Union in search of the best way to deal with liability for damage caused by artificial intelligence. Maastricht J Eur Comp Law:1-6. https:// doi.org/10.1177/1023263X18812333

Courtois G (2016) Robot Intelligents et Responsabilité: quels Régimes, quelles Perspectives? Dalloz IP/IT 6:287-290

Faure MG (2006) Economic criteria for compulsory insurance. Geneva Pap Risk Insur Issues Pract 31:149-168

Hubbard FP (2014) "Sophisticated Robots": balancing liability, regulation, and innovation. Fla Law Rev 66(5):1803-1872

Huttunen A, Kulovesi J, Brace W et al (2010) Liberating intelligent machines with financial instruments. Nordic J Commer Law (2):1-14

Kelley R, Schaerer E, Gomez M et al (2010) Liability in robotics: an international perspective on robots as animals. Adv Robot 24:1861-1871

Leenes R, Palmerini E, Koops BJ et al (2017) Regulatory challenges of robotics: some guidelines for addressing legal and ethical issues. Law Innov Technol 9(1):1-44

Müller VC (2017) Legal vs. ethical obligations - a comment on the EPSRC's principles for robotics. Connect Sci 29(2):137-141 
Palmerini E, Bertolini A, Battaglia F et al (2016) Robolaw: towards a European Framework for robotics regulation. Robot Auton Syst 86:78-85

Richardson BJ (2002) Mandating environmental liability insurance. Duke Environ Law Policy Forum 12:293-329

Robinson H, MacDonald B, Broadbent E (2014) The role of healthcare robots for older people at home: a review. Int J Soc Robot 6:575-591. https://doi.org/10.1007/s12369-014-0242-2

Schwartz GT (1990) The ethics and the economics of tort liability insurance. Cornell Law Rev 75:313-365

Shavell S (2000) On the social function and the regulation of liability insurance. Geneva Pap Risk Insur Issues Pract 25(2):166-179

Skogh G (1998) Development risks, strict liability, and the insurability of industrial hazards. Geneva Pap Risk Insur Issues Pract 23:247-264

Wuytz D (2014) The Product Liability Directive - more than two decades of defective products in Europe. J Eur Tort Law 5(1):1-34

\section{Working Papers}

Teubner G (2018) Digital Personhood? The Status of Autonomous Software Agents in Private Law. Available at https://ssrn.com/abstract $=3177096$ or https://doi.org/10.2139/ssrn.3177096

\section{Reports}

A Common EU Approach to Liability Rules and Insurance for Connected and Autonomous Vehicles European Added Value Assessment, February 2018 available at: http://www. europarl.europa.eu/RegData/etudes/STUD/2018/615635/EPRS_STU(2018)615635_EN.pdf

Commission Staff Working Document Impact Assessment - Accompanying the document Proposal for a Directive of the European Parliament and of the Council amending Directive 2009/103/EC of the European Parliament and the Council of 16 September 2009 relating to insurance against civil liability in respect of the use of motor vehicles, and the enforcement of the obligation to insure against such liability SWD/2018/248 final - 2018/0168 (COD)

Commission Staff Working Document - Liability for Emerging Digital Technologies- Accompanying the document Communication from the Commission to the European Parliament, the European Council, the Council, the European Economic and Social Committee and the Committee of the Regions Artificial intelligence for Europe SWD (2018) 137 final COM (2018) 237 final

Communication from the Commission to the European Parliament and the Council - Insurance Requirements for Aircraft Operators in the EU - A Report on the Operation of Regulation 785/2004 COM (2008) 216 final

European Commission Directorate-General for Internal Market, Industry, Entrepreneurship and SMEs Industrial Transformation and Advanced Value Chains Advanced Engineering and Manufacturing Systems, Guide to Application of the Machinery Directive 2006/42/EC Edition 2.1 - July 2017 (Update of 2nd Edition)

European Commission Public Consultation on Recommendation on Connected and Automated Mobility (CAM), available at https://ec.europa.eu/info/consultations/public-consultation-recom mendation-connected-and-automated-mobility-cam_en 
European Commission, Report from The Commission to the European Parliament, the Council and the European Economic and Social Committee, Fourth Report on The Application of Product Liability Directive, COM (547), 2011

European Commission Staff Working Document - Evaluation of the Machinery Directive - SWD (2018) 160 final

European Parliament Resolution of 16 February 2017 with Recommendations to the Commission on Civil Law Rules on Robotics (2015/2013(INL))

Evaluation of Council Directive 85/374/EEC on the approximation of laws, regulations and administrative provisions of the Member States concerning liability for defective products Final Report, January 2018

Follow up to the European Parliament Resolution of 16 February on Civil Law Rules on Robotics. http://www.europarl.europa.eu/meetdocs/2014_2019/plmrep/COMMITTEES/JURI/DV/2017/ 11-20/A8-0005-2017_EN.pdf

Fondazione Rosselli, Analysis of the Economic Impact of the Development Risk Clause as provided by Directive 85/374/EEC on Liability for Defective Products - Final Report

Mapping the Cost of Non-Europe 2014-2019

Pathway to Driverless Cars: Consultation on proposals to support Advanced Driver Assistance Systems and Automated Vehicles, Government Response 2017 https://assets.publishing.ser vice.gov.uk/government/uploads/system/uploads/attachment_data/file/581577/pathway-to-driv erless-cars-consultation-response.pdf

Pathway to Driverless Cars: Proposals to Support Advanced Driver Assistance Systems and Automated Vehicle Technologies 2016. https://assets.publishing.service.gov.uk/government/ uploads/system/uploads/attachment_data/file/536365/driverless-cars-proposals-for-adas-and_ avts.pdf

Regulating Emerging Robotic Technologies in Europe: Robotics facing Law and Ethics, D6.2 Guidelines on Robotics http://www.robolaw.eu/RoboLaw_files/documents/robolaw_d6.2_ guidelinesregulatingrobotics_20140922.pdf

Report with Recommendations to the Commission on Civil Law Rules on Robotics (2015/2103 (INL))

Summary of the Public Consultation on the Future of Robotics and Artificial Intelligence (AI) with an Emphasis on Civil Law Rules. http://www.europarl.europa.eu/cmsdata/130181/public-con sultation-robotics-summary-report.pdf

\section{Legislative Instruments \& Soft Law Materials}

Automated and Electric Vehicles Act 2018 (UK)

Code Civil Français (France, consolidated version of 1 October 2018)

Code des Assurances (France, consolidated version of 22 November 2018)

Council Directive 85/374/EEC of 25 July 1985 on the Approximation of the Laws, Regulations and Administrative Provisions of the Member States concerning Liability for Defective Products

Directive 2001/95/EC of the European Parliament and of the Council of 3 December 2001 on general product safety

Directive 2006/42/EC of the European Parliament and of the Council of 17 May 2006 on machinery, and amending Directive 95/16/EC (recast)

Directive 2009/103/EC of the European Parliament and of the Council of 16 September 2009 relating to insurance against civil liability in respect of the use of motor vehicles, and the enforcement of the obligation to insure against such liability

Directive 2009/20/EC of the European Parliament and of the Council of 23 April 2009 on the insurance of shipowners for maritime claims 
Directive 2013/30/EU of the European Parliament and of the Council of 12 June 2013 on safety of offshore oil and gas operations and amending Directive 2004/35/EC ('Offshore Safety Directive')

Intelligent Robots Development and Distribution Act 2008 (South Korea)

Principles of European Insurance Contract Law (PEICL)

Principles of Reinsurance Contract Law (PRICL)

Regulation (EU) 2017/745 of the European Parliament and of the Council of 5 April 2017 on medical devices, amending Directive 2001/83/EC, Regulation (EC) No 178/2002 and Regulation (EC) No 1223/2009 and repealing Council Directives 90/385/EEC and 93/42/EEC

Regulation (EC) No 392/2009 of the European Parliament and of the Council of 23 April 2009 on the liability of carriers of passengers by sea in the event of accidents

Regulation (EC) No 785/2004 of the European Parliament and of the Council of 21 April 2004 on insurance requirements for air carriers and aircraft operators

Open Access This chapter is licensed under the terms of the Creative Commons Attribution 4.0 International License (http://creativecommons.org/licenses/by/4.0/), which permits use, sharing, adaptation, distribution and reproduction in any medium or format, as long as you give appropriate credit to the original author(s) and the source, provide a link to the Creative Commons licence and indicate if changes were made.

The images or other third party material in this chapter are included in the chapter's Creative Commons licence, unless indicated otherwise in a credit line to the material. If material is not included in the chapter's Creative Commons licence and your intended use is not permitted by statutory regulation or exceeds the permitted use, you will need to obtain permission directly from the copyright holder. 